\title{
EFEKTIVITAS E-LEARNING TERHADAP HASIL BELAJAR MAHASISWA PADA MATA KULIAH KONSEP DASAR IPS
}

\author{
Tri Wardati Khusniyah \\ Program Studi PGSD, STKIP Modern Ngawi \\ Email: neeaccel@gmail.com
}

\begin{abstract}
Abstrak
Pemanfaatan e-learning pada pembelajaran di Prodi PGSD STKIP Modern Ngawi dilaksanakan untuk meningkatkan pembelajaran mahasiswa dalam pemahaman materi perkuliahan. Tujuan dari penelitian ini adalah mengungkapkan keefektifan media e-learning dalam meningkatkan pemahaman mahasiswa pada mata kuliah konsep dasar IPS yang ditunjukkan melalui hasil belajar mahasiswa. Penelitian dilaksanakan pada tahun 2020 dengan melibatkan 50 mahasiswa PGSD STKIP Modern Ngawi. Teknik pengumpulan data menggunakan instrumen tes awal (pretest) dan tes akhir (posttest). Teknik analisis data menggunakan teknik analisis data kuantitatif untuk melihat signifikansi dan keefektifan, yaitu Paired Sample $t$ Test dan Gain Score. Media e-learning STKIP Modern Ngawi terbukti signifikan dan efektif untuk meningkatkan pemahaman mahasiswa pada mata kuliah konsep dasar IPS dengan nilai gain sebesar 0,712 .
\end{abstract}

Kata Kunci : Keefektifan, Media E-Learning, Hasil Belajar

\section{Abstract}

The utilization of E-Learning in learning at the PGSD Study Program of STKIP Modern Ngawi is carried out to improve student learning in understanding lecture material. The purpose of this study is to reveal the effectiveness of e-learning media in improving students' understanding of social science basic concepts courses that are demonstrated through student learning outcomes. The study was conducted in 2020 involving 50 students of PGSD STKIP Modern Ngawi. The data collection techniques were the initial test instrument (pretest) and final test (posttest). The data analysis techniques used quantitative data analysis techniques to see the significance and effectiveness, namely Paired Sample t Test and Gain Score. The STKIP Modern Ngawi e-learning media has proven to be significant and effective in increasing students' understanding of social science basic courses with a gain value of 0.712 .

Key Words : Effectiveness, E-Learning Media, Learning Outcomes

\section{PENDAHULUAN}

Perkembangan teknologi informasi dan komunikasi memberikan dampak positif pada banyak sektor kehidupan. Salah satunya adalah sektor pendidikan. Pendidikan pada masa kini memanfaatkan perkembangan teknologi untuk mendukung kemajuan pembelajaran, seperti pada pemanfaatan media pembelajaran. Media pembelajaran yang merupakan wujud dari perkembangan teknologi adalah e-learning.

E-learning adalah sistem pembelajaran elektronik yang memberikan kesempatan kepada mahasiswa untuk dapat mengeksplorasi pembelajaran secara online sekaligus sebagai jembatan pembelajaran yang fleksibel dimana saja dan kapan saja [1]. Media e-learning mampu meningkatkan interaktivitas dan efsiensi belajar karena e-learning melibatkan mahasiswa untuk menggali potensi dan berkomunikasi lebih banyak dengan dosen, rekan, serta mengakses lebih banyak materi pembelajaran [2].

E-learning adalah pembelajaran yang dilakukan menggunakan perangkat komputer atau perangkat elektronik untuk mendukung pembelajaran [3]. Pendapat lain yaitu e-learning adalah perangkat peralatan teknologi informasi dan komunikasi yang dimanfaatkan untuk 
meningkatkan pembelajaran, serta digunakan untuk menyampaikan informasi dan menyajikan solusi permasalahan dalam peningkatan pengetahuan [4]. E-learning adalah sebuah interaktivitas yang menarik minat dan perhatian peserta didik dengan melibatkan peserta didik dalam setiap pengalaman belajar pada proses pembelajaran [2].

Berdasarkan definisi dan manfaat elearning yang telah disebutkan, e-learning merupakan salah satu media untuk mewujudkan pembelajaran yang efektif. Pembelajaran yang efektif adalah pembelajaran yang berhasil mencapai tujuan belajar peserta didik sebagaimana yang diharapkan oleh guru/dosen [5]. Proses pembelajaran yang efektif adalah pembelajaran yang berorientasi pada kebutuhan dan kemampuan mahasiswa.

Untuk mencapai pembelajaran yang efektif, dosen perlu memberikan berbagai macam situasi belajar yang dapat menciptakan pengalaman belajar yang bermakna dan menyenangkan, serta menciptakan kondisi dan asas belajar yang diterapkan pada satuan belajar mandiri, interaksi baik antara dosen dan mahasiswa dan antarmahasiswa [5].

Salah satu permasalahan pembelajaran yang dialami oleh dosen pengampu mata kuliah pada awal semester adalah kesulitan penyesuaian dari pada peralihan sistem pembelajaran teacher centered learning atau pembelajaran yang berpusat kepada dosen/guru [6] ke student centered learning atau pembelajaan yang berfokus dan berpusat pada mahasiswa [7]. Pembelajaran pada saat kuliah di perguruan tinggi berbeda dengan pembelajaran di sekolah. Pembelajaran di perguruan tinggi lebih banyak menggunakan pendekatan student centered learning.
Hasil pengamatan sementara selama mengampu mata kuliah konsep dasar IPS, ada beberapa masalah yang muncul pada mahasiswa, yaitu: 1) Sekitar 50\% mahasiswa bersifat pasif pada saat mengikuti perkuliahan. Aktivitas mahasiswa lebih banyak mendengarkan dan mencatat, yang bergantung pada kemampuan dosen dalam menyampaikan materi. 2) Hanya ada satu dua orang saja yang mengemukakan pendapatnya atau bertanya setelah dosen selesai menerangkan. 3) Mahasiswa tidak dapat menyelesaikan tugas mandiri secara tepat waktu, karena ketergantungan kepada dosen masih sangat besar. 4) Penyesuaian diri yang dialami oleh mahasiswa pada saat mengikuti pembelajaran di perguruan tinggi. Mahasiswa pada semester awal belum memiliki kematangan untuk belajar mandiri. Mahasiswa juga masih terbawa dengan pembelajaran pada saat sekolah yang lebih bersifat teacher oriented. Beberapa hal tersebut memberikan pengaruh pada hasil belajar mahasiswa pada mata kuliah konsep dasar IPS ada pada tingkatan rendah. Selain itu, karakteristik mata kuliah konsep dasar IPS memiliki muatan materi yang cakupannya cukup luas dan bersifat teoritis. Maka dari itu, diperlukan penunjang pembelajaran yang berkualitas. Penunjang pembelajaran yang berkualitas dengan melibatkan mahasiswa dalam pengalaman belajar yang bermakna, akan melatih mahasiswa untuk terbiasa belajar mandiri dan mengkonstruksi pengetahuannya sendiri.

Hasil belajar adalah kemampuankemampuan yang telah dimiliki oleh peserta didik setelah ia mengalami proses belajarnya [8]. Hasil belajar yang menjadi objek penilaian pembelajaran berupa kemampuan-kemampuan baru yang diperoleh peserta didik setelah mereka mengikuti proses belajar mengajar dan pengalaman belajar [9]. 
Dengan demikian, dapat disimpulkan bahwa hasil belajar adalah pengetahuan dan kemampuan yang dimiliki mahasiswa setelah menjalani pengalaman belajarnya. Hasil belajar dapat dilihat melalui evaluasi pembelajaran yang dapat diukur kesesuaiannya dengan tujuan pembelajaran. Evaluasi hasil belajar merupakan proses untuk menentukan nilai belajar peserta didik melalui kegiatan penilaian dan/atau pengukuran hasil belajar [8].

Hasil belajar dinyatakan telah tercapai jika terpenuhi dua indikator antara lain: 1) Retensi dan daya serap terhadap bahan pembelajaran menghasilkan prestasi yang tinggi, baik secara individu maupun kelompok. 2) Tercapainya tujuan pembelajaran yang mengacu pada klasifikasi hasil belajar Bloom yaitu aspek kognitif, afektif, dan psikomotor [9].

Berdasarkan uraian yang telah disebutkan, untuk meningkatkan hasil belajar mahasiswa pada mata kuliah konsep dasar IPS, diperlukan adanya upaya inovasi pembelajaran yaitu menggunakan media $e$ learning yang telah tersedia di STKIP Modern Ngawi. Maka dari itu, penelitian ini bertujuan untuk menguji tingkat keefektifan pembelajaran e-learning di prodi PGSD STKIP Modern pada hasil belajar kognitif mahasiswa mata kuliah konsep dasar IPS. Penelitian ini bermanfaat untuk mengetahui pengaruh pembelajaran berbasis e-learning pada hasil belajar mahasiswa yang dapat digunakan sebagai bahan evaluasi dan rekomendasi peningkatan mutu belajar mahasiswa.

\section{METODE}

Penelitian ini menggunakan metode eksperimen dengan One Group Pretest Posttest Design. Subjek penelitian yaitu 50 mahasiswa semester 1 program studi PGSD STKIP Modern Ngawi. Penelitian dilaksanakan pada tahun 2020. Teknik pengumpulan data menggunakan instrumen tes awal (pretest) dan tes akhir (posttest). Rancangan langkah-langkah penelitian One group Pretest Posttest Design digambarkan sebagai berikut: (1) memberikan tes awal (pretest) sebelum pembelajaran menggunakan media $e$ learning, (2) mengadakan pembelajaran menggunakan media e-learning dalam tiga kali tatap muka perkuliahan, (3) memberikan tes akhir (posttest) untuk mengukur capaian hasil belajar kognitif mahasiswa setelah menggunakan media $e$ learning.

Teknik analisis yang digunakan adalah teknik analisis data kuantitatif untuk menganalisis data yang terkumpul dari skor capaian hasil belajar kognitif mahasiswa. Data capaian hasil belajar kognitif mahasiswa dianalisis menggunakan teknik analisis Paired Sample $t$ Test dan Gain Score. Paired Sample $t$ Test berfungsi untuk mengetahui seberapa besar perbedaan yang signifikan antara sebelum dan sesudah pembelajaran menggunakan media e-learning. Paired Sample $t$ Test dihitung menggunakan aplikasi SPSS (Statistical Package for Social Sciences) versi 23. Taraf signifikansi yang digunakan adalah 5\% dengan kriteria keputusan yang diajukan adalah ada perbedaan yang signifikan dalam capaian hasil belajar kognitif mahasiswa pada materi kedudukan IPS dalam kurikulum 2013, apabila nilai signifikansi yang dihasilkan ( $p$-value) lebih kecil dari taraf signifikansi yang ditentukan.

Normalized Gain berfungsi untuk mengetahui apakah media e-learning terbukti efektif dalam meningkatkan hasil belajar kognitif mahasiswa. Gain adalah selisih antara skor tes awal (pretest) dan skor tes akhir (posttest). Rumus nilai N.Gain yaitu: 


$$
g=\frac{\text { Skor Posttest }- \text { Skor Pretest }}{\text { Skor Maksimum - Skor Pretest }}
$$

Setelah diperoleh hasil dari perhitungan tersebut, kemudian menginterpretasikan nilai tersebut dalam kriteria keefektifan pembelajaran yang telah ditentukan sebagaimana dalam Tabel berikut.

Tabel 1. Interpretasi Nilai Gain

\begin{tabular}{cc}
\hline Nilai Gain & Kriteria \\
\hline $\mathrm{g}>0,7$ & Tinggi \\
$0,3<\mathrm{g} \leq 0,7$ & Sedang \\
$\mathrm{g} \leq 0,3$ & Rendah \\
\hline & \multicolumn{2}{c}{ Sumber: [10] }
\end{tabular}

\section{HASIL DAN PEMBAHASAN}

Subjek uji coba pada penelitian ini adalah mahasiswa semester 1 program studi PGSD STKIP Modern Ngawi, karena hasil belajar mahasiswa pada beberapa materi di mata kuliah konsep dasar IPS di kelas ini termasuk rendah. Tahap uji efektivitas berlangsung selama tiga kali tatap muka pembelajaran.

Pertemuan pertama diawali dengan memberikan tes awal (pretest) untuk mengetahui kemampuan awal kognitif mahasiswa mengenai materi kedudukan IPS dalam kurikulum 2013. Setelah pretest dilaksanakan, mahasiswa dipersilakan untuk membuka laptop untuk mengikuti pembelajaran menggunakan media $e$ learning. Proses ini berlangsung hingga pertemuan ketiga, yang pada akhir pembelajaran diberikan tes akhir (posttest) untuk mengetahui kemampuan mahasiswa setelah mengikuti pembelajaran dengan media e-learning.

Pada kedua tahapan test tersebut, mahasiswa diberikan 50 soal dengan tingkat kognitif yang berbeda-beda. Soalsoal pretest posttest yang disajikan disesuaikan dengan soal-soal yang ada pada buku sumber yaitu buku pegangan dosen Konsep dasar IPS.
Kegiatan pretest, pembelajaran dengan media e-learning, dan posttest dilaksanakan dengan lancar dan berjalan sesuai dengan rencana. Pada saat pembelajaran, mahasiswa PGSD dengan antusias mengikuti pembelajaran.

Persentase $75 \%$ mahasiswa menyatakan bahwa pembelajaran menggunakan media e-learning sangat menyenangkan dan meningkatkan motivasi belajar. Media $e$ learning dapat diakses tidak hanya ketika perkuliahan di kampus, tetapi juga di rumah. Mahasiswa menyatakan, melalui media e-learning, bahan-bahan penunjang untuk materi IPS dalam Kurikulum 2013 dapat dengan mudah untuk diakses. Hasil pretest pada materi IPS dalam Kurikulum 2013 disajikan dengan rerata skor. Hasil perhitungan statistik rerata skor pretest dan posttest dapat dilihat pada tabel berikut.

Tabel 2. Rerata Skor Pretest dan Posttest

\begin{tabular}{lllll} 
& $\boldsymbol{N}$ & Minimum & Maximum & Rerata \\
\hline PRE & 50 & 15,00 & 80,00 & 49,30 \\
POST & 50 & 70,00 & 100,00 & 85,40 \\
\hline
\end{tabular}

Tabel tersebut menunjukkan bahwa rerata untuk skor pretest adalah 49,30 dengan skor minimum 15,00 dan skor maksimum 80,00 . Sementara, distribusi frekuensi skor pretest dapat dilihat pada grafik berikut:

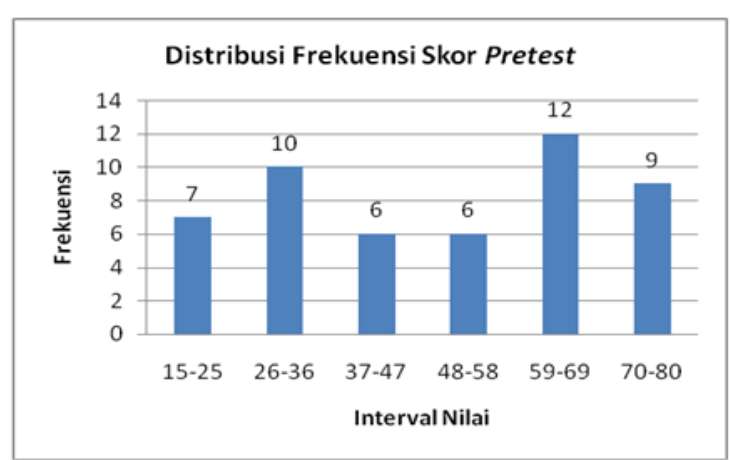

\section{Gambar 1.Grafik Distribusi Frekuensi Skor Pretest}

Grafik tersebut menunjukkan bahwa skor pretest mahasiswa sebagian besar terletak pada interval nilai 59-69 dengan jumlah 12 
mahasiswa. Sementara skor pretest mahasiswa sebagian kecil terletak pada interval nilai 48-58 dan 37-47 dengan jumlah 6 mahasiswa.

Lebih lanjut, berdasarkan Tabel 2 rerata Skor Pretest dan Posttest, diperoleh hasil perhitungan statistik rerata skor posttest adalah 85,40 dengan skor terendah 70,00 dan skor tertinggi 100,00. Distribusi frekuensi skor posttest dapat dilihat pada grafik berikut:

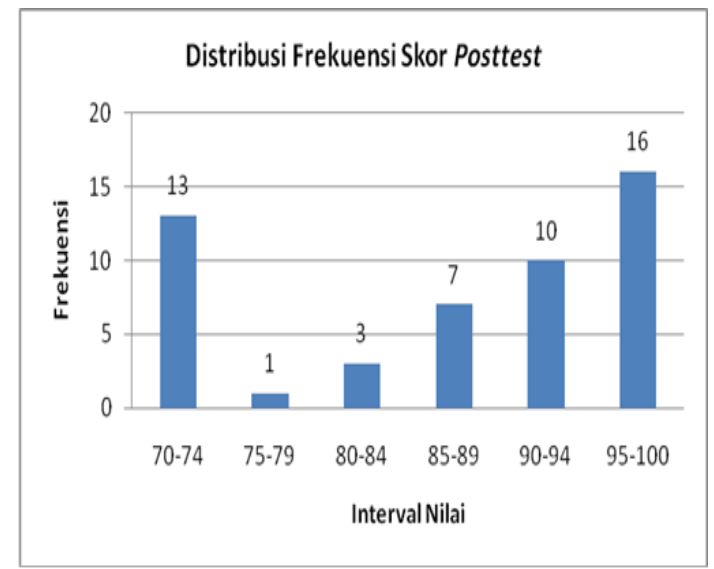

\section{Gambar 2. Grafik Distribusi Frekuensi} Skor Pretest

Grafik di atas menunjukkan bahwa skor posttest mahasiswa sebagian besar terletak pada interval nilai 95-100 dengan frekuensi 16 mahasiswa. Sementara skor posttest mahasiswa sebagian kecil terletak pada interval nilai 75-79 dengan frekuensi 1 mahasiswa. Berdasarkan hasil distribusi frekuensi skor pretest dan posttest, ada peningkatan dalam interval nilai pada sebagian besar mahasiswa yaitu dari interval nilai 59-69 meningkat pada interval nilai $95-100$.

Pada penelitian ini juga dilakukan analisis signifikansi menggunakan uji statistik Paired Sample $t$ Test. Uji signifikansi dilakukan untuk mengetahui apakah media e-learning signifikan dalam meningkatkan hasil belajar kognitif mahasiswa. Hasil analisis signifikansi ditunjukkan pada tabel berikut.
Tabel 3. Korelasi Pretest dan Posttest

\begin{tabular}{lllll}
\hline & & $\boldsymbol{N}$ & Correlation & Sig. \\
\hline Pair 1 & PRE & $\&_{50}$ & \multirow{2}{*}{, 810} &, 000 \\
& POST & & & \\
\hline
\end{tabular}

Pada Tabel di atas, diperoleh nilai signifikansi yang lebih kecil dari taraf signifikansi $(p$-value $<0,05)$ yaitu $p$-value $=0,00$, yang berarti bahwa ada perbedaan yang signifikan antara sebelum pembelajaran menggunakan media $e$ learning dengan sesudah pembelajaran menggunakan media e-learning.

Tahap terakhir adalah menguji tingkat keefektifan media e-learning. Mengacu pada rerata hasil belajar kognitif mahasiswa sebelum dan sesudah menggunakan media e-learning, maka perhitungan keefektifan menggunakan rumus Normalized Gain adalah sebagai berikut.

$$
g=\frac{85,40-49,30}{100,00-49,30}
$$

Hasil Normalized Gain diperoleh nilai gain yaitu 0,712. Jika kita interpretasikan berdasarkan Tabel 1, maka nilai tersebut termasuk dalam kriteria "Tinggi" $(g>0,7)$. Hasil nilai gain menunjukkan bahwa ada peningkatan dalam skor hasil belajar kognitif mahasiswa antara sebelum pembelajaran menggunakan media $e$ learning dengan setelah menggunakan media e-learning. Hal ini menunjukkan bahwa pembelajaran berbasis e-learning sebagai penunjang pembelajaran materi kedudukan IPS dalam kurikulum 2013 yang dikembangkan memiliki tingkat keefektifan yang tinggi untuk meningkatkan pemahaman mahasiswa dalam materi kedudukan IPS dalam kurikulum 2013.

Hasil uji efektivitas tersebut sesuai dengan penelitian yang menyataan bahwa implementasi dengan pembelajaran menggunakan e-learning secara signifikan 
dapat meningkatkan hasil belajar mahasiswa Prodi Pendidikan Ekonomi Universitas Lambung Mangkurat [11]. Sejalan dengan hasil tersebut, penelitian lain menyatakan bahwa pembelajaran berbantuan internet (e-learning) dapat meningkatkan hasil belajar mahasiwa Prodi Pendidikan Matematika Universitas Muhammadiyah Jakarta dengan peningkatan nilai rata-rata dari 74 pada siklus I menjadi 86 pada siklus II [12]. Selain itu, hasil penelitian lainnya menunjukkan bahwa hasil belajar mahasiswa yang menggunakan sistem $E$ learning adaptif jauh lebih maksimal dari hasil belajar mahasiswa yang tidak menggunakan sistem E-learning nonadaptif [13]. Beberapa hasil penelitian yang relevan tersebut, juga memperkuat bukti bahwa pembelajaran menggunakan media e-learning mampu meningkatkan hasil belajar mahasiswa.

Penerapan pembelajaran menggunakan media e-learning berdampak pada tercapainya pembelajaran yang efektif. Pembelajaran yang efektif menuntut kegiatan pembelajaran yang mampu memberikan pengalaman belajar yang bermakna dan menyenangkan. Melalui media e-learning, mahasiswa dapat menciptakan pengetahuannya sendiri, menggali banyak bahan materi, dan belajar secara mandiri. Selain itu, media $e$ learning menjadi solusi mahasiswa dalam peralihan pembelajaran dari pembelajaran teacher centered learning menuju student centered learning. Pembelajaran menggunakan e-learning juga melatih mahasiswa untuk belajar secara mandiri karena memfasilitasi mahasiswa untuk mengakses sumber referensi yang diinginkan dengan lebih cepat dan mudah, sehingga dapat mencapai hasil belajar yang lebih baik [13].

Media e-learning juga menjadi media yang efektif dalam menyajikan materi-materi pada mata kuliah konsep dasar IPS. Materi konsep dasar IPS yang lebih banyak memuat teori, sangat efektif jika disajikan menggunakan media e-learning yang dapat memfasilitasi mahasiswa untuk mengakses lebih banyak bahan materi. Selain itu, media e-learning juga memudahkan mahasiswa dalam mengakses referensi, penugasan, menghemat biaya dan waktu [14].

Banyaknya materi dalam mata kuliah konsep dasar IPS terfasilitasi dengan media e-learning. Mahasiswa menjadi tidak bosan karena dapat berinteraksi menggunakan fitur e-learning seperti fitur interaktivitas, kuis, dan latihan dengan berbagai macam bentuk. Media e-learning juga memudahkan interaksi dosen dan mahasiswa, pembelajaran tidak hanya satu arah, mahasiswa dan dosen dapat menciptakan pengalaman dan variasi sumber belajar secara online [15].

Pembelajaran menggunakan media $e$ learning juga mendukung terciptanya pembelajaran Student Centered Learning yang menuntut mahasiswa untuk secara aktif melakukan diskusi dengan dosen sebagai fasilitator jika menemui kesulitan. Keaktifan mahasiswa diharapkan mampu menumbuhkan daya kreativitas mahasiswa yang berdampak pada peningkatan hasil belajar.

\section{SIMPULAN}

Simpulan penelitian ini adalah media $e$ learning STKIP Modern Ngawi memfasilitasi belajar mahasiswa pada mata kuliah konsep dasar IPS, khususnya materi kedudukan IPS dalam kurikulum 2013 secara mandiri dan melibatkan mahasiswa dalam pemelajaran dengan interaktivitas cukup tinggi. Pembelajaran menggunakan media e-learning ini terbukti efektif untuk meningkatkan pemahaman mahasiswa dalam mata kuliah konsep dasar IPS, khususnya materi kedudukan IPS dalam 
kurikulum 2013. Terbukti dengan adanya peningkatan rerata capaian hasil belajar kognitif mahasiswa setelah pembelajaran.

Ada perbedaan hasil belajar kognitif mahasiswa yang signifikan antara sebelum dan sesudah menggunakan media $e$ learning. Selain itu, tingkat keefektifan media e-learning ada pada nilai yang "Tinggi", dengan nilai gain sebesar 0,712.

Lebih lanjut, mahasiswa diharapkan dapat menggunakan media e-learning secara intensif, agar memperoleh hasil belajar yang lebih baik. Pada pengembangan media e-learning lebih lanjut, pengujian efektivitas media e-learning tidak hanya untuk menilai hasil belajar kognitif mahasiswa, tetapi juga pada penilaian hasil belajar yang lain.

\section{DAFTAR PUSTAKA}

[1] D. Zhang, L. Zhou, R. O. Briggs, and J. F. Nunamaker. "Instructional Video in E-learning: Assessing the Impact of Interactive Video on Learning Effectiveness". Information \& Management, vol. 43, no. 1, pp. 15-27, 2006.

[2] D. Ariani. "Komponen Pengembangan E-Learning". JPI LIVes, vol. 1, no. 1, pp. 58-64, 2018.

[3] J. L. Moore, C. Dickson-Deane, and K. Galyen. "E-Learning, Online Learning, and Distance Learning Environments: Are They the Same?". The Internet and Higher Education, vol. 14, no. 2, pp. 129-135, 2011.

[4] R. Roberts. "Video Conferencing in Distance Learning: a New Zealand Schools' Perspective". Journal of Distance Learning, vol. 13, no. 1, pp. 91-107, 2009.

[5] P. Setyosari. "Menciptakan Pembelajaran yang Efektif dan Berkualitas". Jinotep, vol. 1, no. 1, pp. 20-30, 2017.

[6] M. A. Kurniawan, A. Miftahillah, dan N. M. Nasihah. "Pembelajaran
Berbasis Student-Centered Learning di Perguruan Tinggi: Suatu Tinjauan di UIN Sunan Kalijaga Yogyakarta". lp, vol. 21, no. 1, pp. 1-11, 2018.

[7] R. R. Antika. "Proses Pembelajaran Berbasis Student Centered Learning (Studi Deskriptif di Sekolah Menengah Pertama Islam Baitul 'Izzah, Nganjuk)'. BioKultur, vol. 3, no. 1, pp. 251-263, 2014.

[8] D. Firmansyah. "Pengaruh Strategi Pembelajaran dan Minat Belajar terhadap Hasil Belajar Matematik". JURNAL PENDIDIKAN UNSIKA, vol. 3, no. 1, pp. 34-44, 2015.

[9] W. - dan L. Widayanti. "Peningkatan Aktivitas Belajar dan Hasil Belajar Siswa dengan Metode Problem Based Learning pada Siswa Kelas VIIA MTs Negeri Donomulyo Kulon Progo Tahun Pelajaran 2012/2013". J. Fis. Indones., vol. 17, no. 49, pp. 32-35, 2014.

[10] A. R. Pranjono. "Efektivitas Model Pembelajaran Project Based Learning pada Mata Pelajaran Gambar Teknik Kelas X Program Keahlian Teknik Instalasi Tenaga Listrik di SMKN 2 Klaten”. Jurusan Pendidikan Teknik Mekatronika, vol. 4, no. 4, pp. 307-313, 2015.

[11] M. Meliyani, S. Supriyanto, dan M. Rahmattullah. "Pengaruh Pemanfaatan Simari sebagai Implementasi Pembelajaran Berbasis E-learning terhadap Hasil Belajar Mahasiswa Prodi Pendidikan Ekonomi”. JPIS, vol. 29, no. 1, pp. $1-8,2019$.

[12] R. Widiyasari dan J. K. A. Dahlan. "Meningkatkan Aktivitas dan Hasil Belajar Mahasiswa Menggunakan Mind Map Berbantuan E-Learning". Jurnal Teknodik, vol. 21, no. 1, pp. 27-43, 2017.

[13] M. Annisa. "Meningkatkan Hasil Belajar Fisika Mahasiswa PGSD Melalui Pembelajaran Berbantuan 
Internet". Jurnal Lentera Sains (Lensa), vol. 6, no. 2, pp. 61-67, 2016.

[14] H. Istikhomah, I. A.S, dan D. T. P.S, "Persepsi Mahasiswa tentang Media Pembelajaran E-Learning Students Perception E-Learning in Obstetrics Departement". Jurnal Ilmu
Kebidanan, vol. 2, no. 2, pp. 107114, 2014.

[15] C. indah Nartani, K. Wardani, dan B. ebi Praheto. "Strategi Peningkatan Penerapan Metode Pembelajaran Elearning pada Program Studi PGSD FKIP UST". Varidika, vol. 30, no. 1, pp. 12-20, 2018. 